\title{
Pengembangan Lembar Kerja Peserta Didik (LKPD) Laju Reaksi Berbasis Inkuiri Terstruktur Kelas XI SMA
}

\author{
R Efliana ${ }^{1}$ and M Azhar ${ }^{*}$ \\ ${ }^{1}$ Pendidikan Kimia, Universitas Negeri Padang, J1. Prof. Dr. Hamka Air Tawar Barat, \\ Padang Utara, Sumatera Barat 25171, Indonesia \\ *minda@fmipa.unp.ac.id
}

\begin{abstract}
Learner Worksheet (LKPD) of reaction rates based structured inquiry in class XI SMA had been dertemine validity and practicality. The type of research used is Research and Development (R\&D). The development model was a 4-D model consisting of 4 stages, namely (1) Define, (2) Design, (3) Develop, (4) Desseminate. The disseminate stage was not carried out due to time and cost constraints. The research instrument used was a questionnaire validation and practicality questionnaire. The validation questionnaire was filled by 3 chemistry lecturers from FMIPA UNP and 2 chemistry teachers from SMAN 2 Lubuk Basung. Practicality questionnaire was filled by 2 chemistry teachers and 30 students of class XII MIPA 3 SMAN 2 Lubuk Basung. Data were analyzed using kappa moments. The average kappa moment of validity test was 0.87 with a very high validity category. The average kappa moment of teacher were 0,88 with a very high practicality category. The average kappa moment of student were 0,87 with a very high practicality category. Thus, it was concluded that reaction rates LKPD based on structured inquiry was valid and practice.
\end{abstract}

\section{Pendahuluan}

Materi laju reaksi merupakan salah satu materi pelajaran kimia kelas XI semester satu yang dianggap sulit bagi peserta didik. Karakteristik materi laju reaksi bersifat abstrak, memerlukan kemampuan pemahaman, mengahafal, menghitung dan menganalisis serta keaktifan peserta didik untuk berlatih sehingga peserta didik benar-benar memahami konsep. Berdasarkan pengisian angket yang telah dilakukan di SMAN 2 Lubuk Basung diperoleh bahwa beberapa peserta didik mengalami kesulitan dalam memahami konsep pada materi laju reaksi. Dalam proses pembelajaran, konsep merupakan hal yang perlu dipahami, dipelajari dan dikuasai oleh peserta didik [1]. Rendahnya pemahaman konsep peserta didik pada materi laju reaksi, sehingga dibutuhkan metode atau model-model pembelajaran, media dan bahan ajar yang sesuai [2].

Bahan ajar yang sesuai mempengaruhi ketercapaian tujuan pembelajaran. Salah satu bahan ajar yaitu lembar kerja peserta didik (LKPD). Lembar kerja peserta didik (LKPD) merupakan sarana kegiatan pembelajaran yang dapat membantu mempermudah pemahaman materi yang dipelajari [3]. LKPD berisikan panduan belajar peserta didik yang digunakan untuk melakukan kegiatan penyelidikan atau pemecahan masalah. Panduan dalam LKPD dapat digunakan sebagai latihan bagi peserta didik untuk mengembangkan aspek yang harus dimiliki dalam proses pembelajaran [4].

Ada 6 unsur utama yang harus termuat dalam LKPD, yaitu: judul, petunjuk belajar, kompetensi dasar atau materi pokok, informasi pendukung, tugas atau langkah kerja, dan penilaian [5]. Dalam proses pembelajaran berdasarkan kurikulum 2013 digunakan pendekatan saintifik. Pendekatan saintifik adalah proses pembelajaran yang dirancang sedemikian rupa agar peserta didik secara aktif mengonstruk konsep, hukum atau prinsip melalui tahapan-tahapan mengamati, merumuskan masalah, mengajukan atau merumuskan hipotesis, mengumpulkan data dengan berbagai teknik, menganalisis data, menarik kesimpulan dan mengomunikasikan konsep, hukum atau prinsip yang ditemukan [6]. Salah satu model pembelajaran yang sesuai dengan pendekatan saintifik adalah inkuiri. 
Inkuiri dibedakan menjadi empat tingkatan, yaitu confirmation inquiry (inkuiri konfirmasi), structured inquiry (inkuiri terstruktur), guided inquiry (inkuiri terbimbing), dan open inquiry (inkuiri terbuka) [7]. Pada inkuiri terstruktur, siswa menyelidiki pertanyaan atau permasalahan yang diberikan oleh guru melalui suatu prosedur yang telah ditentukan dan menerima petunjuk dari tiap-tiap prosedur [8].

Pengembangan LKPD yang berbasis inkuiri terstruktur ini disusun berdasarkan tahapan-tahapan belajar inkuiri terstruktur yaitu: observasi, hipotesis, koleksi dan analisis data, serta kesimpulan [8]. Pada pembelajaran inkuiri terstruktur, peserta didik harus mengembangkan kemampuan dasarnya dalam penyelidikan. Hal ini karena peserta didik akan terlibat secara langsung dalam melakukan pengamatan, hipotesis, mengumpulkan dan mengolah data, menarik kesimpulan, dan menemukan solusi.

LKPD berbasis inkuiri terstruktur ini dapat membantu peserta didik dalam menyelidiki masalah berdasarkan tahapan-tahapan yang diberikan oleh guru. LKPD mambantu peserta didik memahami materi, melakukan eksperimen, dan meningkatkan hasil belajar peserta didik [9].

Dari hasil wawancara dan penyebaran angket di sekolah SMA Negeri 2 Lubuk Basung, dan SMA Pembangunan Laboratorium UNP, diperoleh informasi bahwa dalam mengajar guru menggunakan bahan ajar berupa buku paket, LKPD, dan powerpoint. Lembar kerja peserta didik yang ada berupa lembar diskusi yang terdiri dari 1 atau 2 lembar kertas berisi soal-soal berupa tugas dan tidak memiliki gambar yang berwarna sehingga LKPD tersebut kurang mampu menarik minat peserta didik untuk membacanya.

Berdasarkan latar belakang di atas, maka penelitian penentuan validitas dan praktikalis pengembangan Lembar Kerja Peserta Didik (LKPD) pada materi reaksi laju reaksi berbasis inkuiri terstruktur penting dilakukan. Penelitian ini bertujuan untuk menghasilkan LKPD yang valid dan praktis untuk materi reaksi laju reaksi berbasis inkuiri terstruktur untuk kelas XI SMA.

\section{Metode}

Jenis penelitian ini merupakan penelitian dan pengembangan atau Research and Development (R\&D). R\&D merupakan suatu proses atau langkah-langkah untuk mengembangkan produk baru atau menyempurnakan produk yang telah ada. Model pengembangan yang digunakan ini adalah model 4-D (four D models) yang terdiri dari 4 tahap, yaitu define, design, develop, dan disseminate. Namun penelitian ini dibatasi sampai tahap develop yaitu uji validitas dan praktikalitas LKPD. Subjek dalam penelitian ini adalah 3 orang dosen kimia FMIPA UNP, 2 orang guru kimia dan 30 orang siswa kelas XII MIPA 3 di SMAN 2 Lubuk basung.

Pada tahap define (pendefinisian) dilakukan penetapan dan pendefinisian syarat-syarat pembelajaran. Tahap ini meliputi: (a) analisis ujung-depan; (b) analisis siswa; (c) analisis tugas; (d) analisis konsep; (e) perumusan tujuan pembelajaran. Tahap design (perancangan) dilakukan untuk merancang LKPD laju reaksi berbasis inkuiri terstruktur. Tahap develop (pengembangan) dilakukan untuk menghasilkan LKPD laju reaksi berbasis inkuiri terstruktur yang valid dan praktis digunakan dalam proses pembelajaran siswa SMA. Instrumen pengumpulan data penelitian yang digunakan adalah angket validitas (ditujukan kepada dosen kimia FMIPA UNP dan guru kimia SMA) dan angket praktikalitas (terdiri dari angket respon guru dan siswa).

Data yang diperoleh dianalisis menggunakan formula Kappa Cohen di bawah ini.

$$
\text { momen kappa }(\kappa)=\frac{\rho_{o}-\rho_{e}}{1-\rho_{\varepsilon}}
$$

Keterangan:

$\kappa=$ Momen Kappa

$\rho_{0}=$ Proporsi yang terealisasi

$\rho_{\varepsilon}^{o}=$ Proporsi yang tidak terealisasi

Berdasarkan nilai momen Kappa yang diperoleh, dapat diambil kesimpulan seperti yang terdapat pada tabel 1 . 
Tabel 1. Kategori Keputusan Berdasarkan Momen Kappa $(\kappa)$

\begin{tabular}{c|c} 
Interval & Kategori \\
\hline $0,81-1,00$ & Sangat tinggi \\
\hline $0,61-0,80$ & Tinggi \\
\hline $0,41-0,60$ & Sedang \\
\hline $0,21-0,40$ & Rendah \\
\hline $0,01-0,20$ & Sangat rendah \\
\hline$\leq 0,00$ & Tidak valid
\end{tabular}

\section{Hasil dan Diskusi}

\subsection{Tahap Pendefinisian}

3.1.1. Analisis ujung depan. Analisis ujung depan (awal-akhir) diperoleh data berupa hasil wawancara yang menyatakan bahwa peserta didik belum seutuhnya mampu memahami konsep pada materi laju reaksi. Guru harus lebih banyak berperan untuk dapat menanamkan konsep, khususnya pada materi laju reaksi ini. Dari hasil wawancara dan penyebaran angket di sekolah SMA Negeri 2 Lubuk Basung, dan SMA Pembangunan Laboratorium UNP, telah menggunakan lembar kerja peserta didik yang berupa lembar diskusi yang terdiri dari 1 atau 2 lembar kertas berisi soal-soal berupa tugas dan tidak memiliki gambar yang berwarna sehingga LKPD tersebut kurang mampu menarik minat peserta didik untuk membacanya. LKPD yang sudah ada lebih bersifat melatih peserta didik dalam menjawab soal tanpa adanya penjelasan lebih lanjut dari soal tersebut, sehingga sulit memeberi umpan balik dari pertanyaan yang ada untuk memberikan penguatan konsep kepada peserta didik. LKPD yang digunakan belum sesuai dengan kebutuhan belajar peserta didik untuk dapat menemukan sediri konsep pembelajaran. Oleh sebab itu dirancang LKPD materi laju reaksi berbasis inkuiri terstruktur yang dapat membantu pesera didik dalam menemukan sendiri konsep pembelajaran serta dapat meningkatkan aktifitas, minat dan motivasi peserta didik untuk belajar.

3.1.2. Analisis siswa. Berdasarkan hasil wawancara dengan guru diperoleh data bahwa kemampuan akademik dan motivasi belajar siswa kelas XI secara umum tergolong cukup. Berdasarkan teori piaget mengenai tahap perkembangan anak, anak yang berumur 12-18 tahun berada pada tahap operasional formal. Pada tahap tersebut anak sudah dapat berpikir secara abstrak dan logis. Disamping itu, pada tahap ini anak juga telah mampu berpikir sistematik untuk memecahkan masalah melalui kegiatan eksperimentasi seperti menarik kesimpulan, menafsirkan dan mengembangkan hipotesis [8]. Karakteristik peserta didik ini dijadikan sebagai salah satu pertimbangan dalam mengembangkan Lembar Kerja Peserta Didik (LKPD) berbasis inkuiri terstruktur.

3.1.3. Analisis tugas. Analisis tugas dilakukan dengan cara menganalisis kompetensi dasar (KD) berdasarkan silabus kurikulum 2013 revisi 2018. Pembelajaran dengan menggunakan model inkuiri terstruktur terdapat langkah-langkah pembelajaran, yaitu observasi, hipotesis, koleksi dan pengolahan data, dan kesimpulan. Berdasarkan silabus mata pelajaran kimia kurikulum 2013 revisi 2018, ada 4 Kompetensi Dasar (KD) yang harus dikuasai oleh peserta didik yaitu KD 3.6 Menjelaskan faktor-faktor yang mempengaruhi laju reaksi menggunakan teori tumbukan, KD3.7 Menentukan orde reaksi dan tetapan laju reaksi berdasarkan data percobaan, KD 4.6 Menyajikan hasil penelusuran informasi caracara pengaturan dan penyimpanan bahan untuk mecegah perubahan fisik dan kimia yang tak terkendali dan KD 4.7 Merancang, melakukan, dan menyimpulkan serta meyajikan hasil percobaan faktor-faktor yang mempengaruhi laju reaksi dan orde reaksi.

3.1.4. Analisis konsep. Konsep-konsep yang terdapat pada materi laju reaksi disusun secara hirarki menjadi peta konsep. Konsep-konsep tersebut dianalisis berdasarkan buku kimia universitas dan kimia SMA. Beberapa konsepnya, yaitu perubahan konsentrasi, perubahan waktu, reaktan, produk, konsentrasi, suhu, luas permukaan, katalis, tumbukan partikel, tumbukan efektif, tumbukan tidak efektif, energi 
aktivasi, katalis homogen, katalis heterogen, hukum laju, konstanta laju reaksi, orde reaksi, konsentrasi reaktan, orde nol, orde satu dan orde dua.

3.1.5. Analisis tujuan pembelajaran. Tujuan pembelajaran yang telah dirumuskan untuk materi laju reaksi pada LKPD mengacu pada penulisan tujuan pembelajaran berdasarkan Kurikulum 2013 revisi 2018, yaitu: Melalui model pembelajaran inkuiri terstruktur dengan menggali informasi dari berbagai sumber belajar, penyelidikan sederhana dan mengolah informasi, diharapkan peserta didik terlibat aktif selama proses belajar mengajar berlangsung, memiliki sikap ingin tahu, teliti dalam melakukan tanggung jawab dalam menjawab pertanyaan, memberi saran dan kritik, serta peserta didik mampu menjelaskan faktor-faktor yang mempengaruhi laju reaksi menggunakan teori tumbukan, menentukan orde reaksi dan retapan laju reaksi berdasarkan data hasil percobaan, dapat menyajikan cara-cara merancang, melakukan dan menyimpulkan serta menyajikan hasil percobaan faktor-faktor yang mempengaruhi laju reaksi dan orde reaksi.

\subsection{Tahap Perancangan}

Pada tahap perancangan ini sesuai dengan hasil pengisian angket siswa SMAN 2 Lubuk Basung, yang mana siswa menginginkan LKPD yang mudah dipahami, menarik dan bergambar. LKPD laju reaksi ini disusun memuat beberapa komponen sebagai berikut: 1) cover; 2) kata pengantar; 3) daftar isi; 4) petunjuk penggunaan modul; 5) kompetensi inti; 6) kompetensi dasar; 7) indikator pencapaian kompetensi; 8) tujuan pembelajaran; 9) peta konsep; 10) pendahuluan; 11) lembar kegiatan; 12) lembar kerja; 13) lembar evaluasi ; 14) kunci jawaban lembar kegiatan; 15) kunci jawaban lembar kerja; 16) kunci jawaban evaluasi.Cover dan lembar kegiatan d dapat dilihat pada Gambar 1 dan 2.

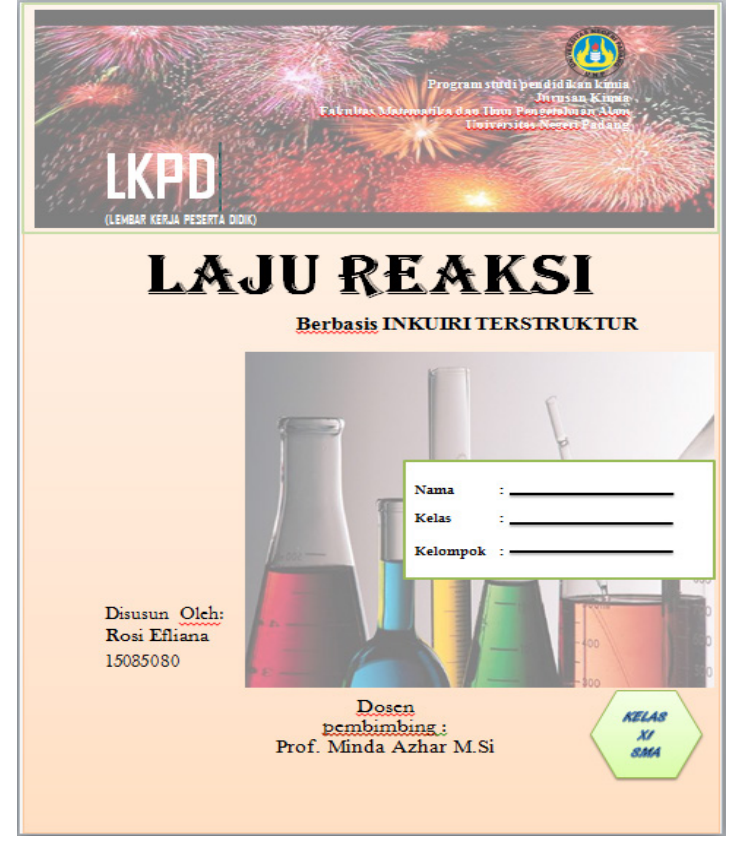

Gambar 1. Cover LKPD

Bagian cover LKPD memuat identitas LKPD yang meliputi nama LKPD, judul materi, sasaran pengguna, nama penulis dan nama dosen pembimbing. Nama LKPD dan judul materi dimuat untuk memberikan informasi tentang model pembelajaran yang digunakan dalam LKPD yaitu inkuiri terstruktur dan judul materi yang ada pada LKPD yaitu materi laju reaksi Cover dirancang dengan warna yang menarik untuk dapat menimbulkan ketertarikan peserta didik untuk membaca dan mempelajarinya. Cover LKPD juga dilengkapi dengan gambar yang berhubungan dengan materi laju reaksi. 
Dalam kehidupan sehari-hari banyak ditemukan peristiwa yang berhubungan dengan reaksi kimia. Reaksi kimia berlangsung dengan kecepatan/ berlangsung lambat. Amatilah Gambar

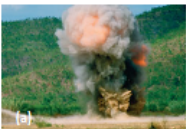

$1 \mathrm{~s}$

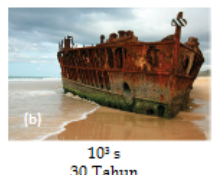

Gambar 2: (a) Bom yang meledak, (b) perkaratan besi pada kapal(Brown, dkk 2012: 558)

Dari Gambar 2 di atas, dapat kitaketahui mana reaksi yang berlanosung lama dan mana reaksi yang berlangsung cepat. Laju ledakan terjadi dalam bilangan detik, laju perkaratan/korosi dapat terjadi selama bertahun-tahun. Dari ilustrasi tersebut, tampak bahwa laju selalu berhubungan dengan perubahan yang terjadi dalam satuan waktu tertentu.

Ananda sudah mengenal istilah laju dan kecepatan untuk benda-benda yang bergerak pada pelajaran fisika. Kecepatan merupakan perpindahan suatu benda dibagi selang waktu tempuh. Sementara laju merupakan perbandingan jarak yang

Gambar 2. Lembar Kegiatan

Lembar kerja siswa berisi materi pelajaran laju reaksi yang disusun berdasarkan model inkuiri terstruktur yang terdiri dari 4 tahap: Observasi, Hipotesis, Koleksi dan Organisasi data, dan Kesimpulan. Pada tahap observasi, peserta didik mengobservasi sebuah fenomena atau permasalahan nyata yang akan menarik minat belajar peserta didik.

\subsection{Tahap Pengembangan}

3.3.1. Uji validasi. Uji validitas merupakan penilaian terhadap rancangan suatu produk. Aspek penikaian dibagi menjadi beberapa komponen yang terdiri dari komponen isi, komponen kebahasaan, komponen penyajian, dan komponen kegrafikan [10]. Uji validitas merupakan penilaian terhadap rancangan suatu produk. Aspek penilaian dibagi menjadi beberapa komponen yang terdiri dari komponen isi, komponen kebahasaan, komponen penyajian, dan komponen kegrafikaan [4]. Validasi dilakukan oleh 3 orang dosen kimia FMIPA UNP dan 2 orang guru kimia SMAN 2 Lubuk Basung sebagai validator. Validator merupakan seorang pakar yang jumlahnya minimal tiga orang untuk menguji validitas instrumen [11]. Kritikan, masukan, dan saran dari validator menjadi bahan pertimbangan untuk merevisi LKPD Laju Reaksi berbasis inkuiri terstruktur kelas XI SMA. Hasil yang diperoleh dapat dilihat pada Gambar 3.

\section{moment kappa}

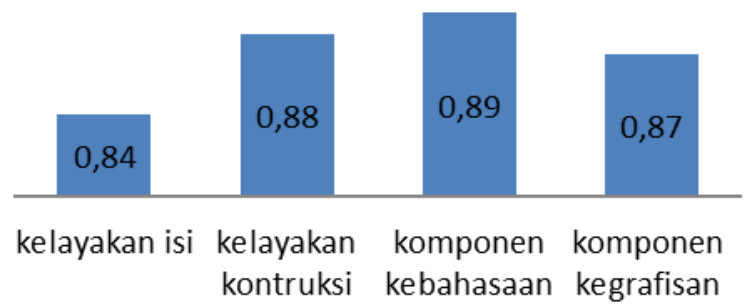

Gambar 3. Hasil Analisis Data Validitas oleh Validator 
Hasil analisis data dari masing-masing komponen oleh validator diperoleh momen kappa yaitu, komponen kelayakan isi 0,84 dengan kategori sangat tinggi, komponen penyajian 0,88 dengan kategori sangat tinggi, komponen kebahasaan 0,89 dengan kategori sangat tinggi dan komponen kegrafisan 0,87 dengan kategori sanggat tinggi.

Lembar validasi berisi 23 aspek penilaian yang memuat 4 komponen yaitu komponen kelayakan isi, komponen penyajian, komponen kebahasaan, dan komponen kegrafisan. Data penilaian lembar validasi LKPD berbasis inkuiri terstruktur tersebut dianalisis dengan menggunakan formula kappa cohen. Berdasarkan hasil penilaian dari kelima validator terhadap LKPD yang dikembangkan, diperoleh hasil bahwa LKPD yang dikembangkan memiliki kevalidan yang sangat tinggi dengan nilai rata-rata momen kappa yaitu 0,87 . Dengan demikian hasil dari LKPD yang dikembangkan sudah valid. Hal ini menunjukkan bahwa LKPD laju reaksi berbasis inkuiri terstruktur telah sesuai dengan komponenkomponennya. Suatu produk pengembangan dikatakan valid jika sesuai dengan teori yang memadai dan semua komponen saling berhubungan secara konsisten [12].

Penilaian validator terhadap LKPD yang dikembangkan dikatakan sudah valid karena LKPD yang dikembangkan penulis sudah memenuhi kriteria yang sesuai dengan alat penilaiannya (lembar validasi). Ada terdapat 4 komponen yang dinilai oleh validator. Dari segi komponen kelayakan isi pada LKPD laju reaksi berbasis inkuiri terstruktur memiliki kategori kevalidan sangat tinggi dengan nilai momen kappa 0,84 . Hal ini dapat disimpulkan dari segi kelayakan isi LKPD yang dikembangkan telah valid dan sudah sesuai dengan KD. Selain itu, model yang terdapat pada LKPD berarti telah sesuai dengan materi yang diajarkan, mudah dimengerti dan dapat diekplorasi untuk menjawab pertanyaan yang terdapat pada LKPD serta dapat mengarahkan dan membimbing untuk menemukan konsep.

Komponen kedua yang menjadi penilaian oleh validator adalah komponen penyajian. Dari segi komponen penyajian pada LKPD laju reaksi berbasis inkuiri terstruktur memiliki kategori kevalidan yang sangat tinggi dengan nilai momen kappa yang diperoleh 0,88 . Hal ini menunjukan bahwa LKPD yang dikembangkan telah valid dari segi komponen penyajiannya yang meliputi penyusunan LKPD yang sistematis mulai dari judul, KI, KD, IPK serta model inkuiri terstruktur yang digunakan telah disusun berdasarkan tahapan belajar inkuiri terstruktur. Tahapan model inkuiri tersturktur adalah observasi, hipotesis, koleksi dan organisasi, dan kesimpulan[7]. Pada tahapan tersebut terdapat gambar dan pertanyaan-pertanyaan yang berhubungan dengan materi yang dibahas. Hal ini bertjuan agar siswa lebih termotivasi dalam belajar serta serta untuk meningkatkan pemahaman siswa terhadap materi tersebut. Pada LKPD ini juga dilengkapi dengan soal evaluasi. Soal evaluasi merupakan alat yang digunakan untuk mengukur keberhasilan atas tercapainya tujuan pembelajaran yang telah dirumuskan [13]. Komponen ketiga yang menjadi penilaian oleh validator yaitu komponen kebahasaan. Dari segi kebahasaan pada LKPD laju reaksi berbasis inkuiri terstruktur memiliki kategori kevalidan yang sangat tinggi dengan nilai momen kappa sebesar 0,89. Berdasarkan hal tersebut, dapat disimpulkan bahwa LKPD yang dikembangkan telah valid dari segi kebahasaan karena bahasa yang digunakan sudah komunikatif, dan sesuai dengan kaidah ejaan bahasa Indonesia.

Komponen terakhir yang menjadi penilaian oleh validator adalah komponen kegrafisan. Dari segi kegrafisan pada LKPD laju reaksi berbasis inkuiri terstruktur memiliki kategori kevalidan sangat tinggi dengan nilai momen kappa 0,87. Berdasarkan hal tersebut, dapat disimpulkan bahwa LKPD yang dikembangkan telah valid dari segi kegrafisan karena gambar dan jenis huruf yang terdapat pada LKPD sudah dapat teramati dan dapat dibaca dengan jelas dan LKPD yang dikembangkan telah teratur dari segi tata letak serta pemilihan warna dapat menarik perhatian peserta didik.

Kevalidan LKPD laju reaksi berbasis inkuiri terstruktur meskipun dinyatakan memiliki kevalidan dengan kategori sangat tinggi, masih terdapat beberapa komponen yang harus diperbaiki sesuai dengan sara yang diberikan oleh validator, maka dilakukan revisi terhadap LKPD yang dikembangkan untuk selanjutnya dapat diujicobakan.

3.3.2. Revisi. Berdasarkan saran yang diberikan oleh validator (pada uji validitas) dilakukan revisi terhadap rancangan LKPD laju reaksi berbasis inkuiri terstruktur. Tujuan dari tahapan ini yaitu memperbaiki bagian LKPD yang dinilai kurang tepat oleh validator sebelum dilakukan uji coba. LKPD yang sudah diperbaiki kemudian diberikan kepada validator untuk didikusikan lebih lanjut sebelum uji coba. Setelah dilakukan validasi terhadap LKPD tersebut maka terdapat beberapa saran dan komentar 
dari validator guna memperbaiki LKPD. Perbaikan yang dilakukan terhadap LKPD ini sebagai berikut: 1) Memperbaiki peta konsep, 2) Memperbaiki gambar yang disajikan kurang jelas, 3) Bagian hipetesis cukup pertanyaan yang mengarahkan, 4) Bagian koleksi dan organisasi data, pertanyaan diperbaiki untuk dapat membuat persamaan, 5) Pemberian No gambar harus diperhatikan, 6) Perbaikan cara kerja pada percoabaan praktikum.

3.3.3. Uji coba. Pada tahap uji praktikalitas diperoleh data uji kepraktisan melalui angket praktikalitas yang diberikan kepada guru kimia dan peserta didik kelas XII SMAN 2 Lubuk Basung.Data praktikalitas diperoleh dari angket respon guru dan siswa. Hasil analisis data penilaian praktikalitas LKPD laju reaksi berbasis inkuiri terstruktur dari guru dan siswa dapat dilihat pada Gambar 4.

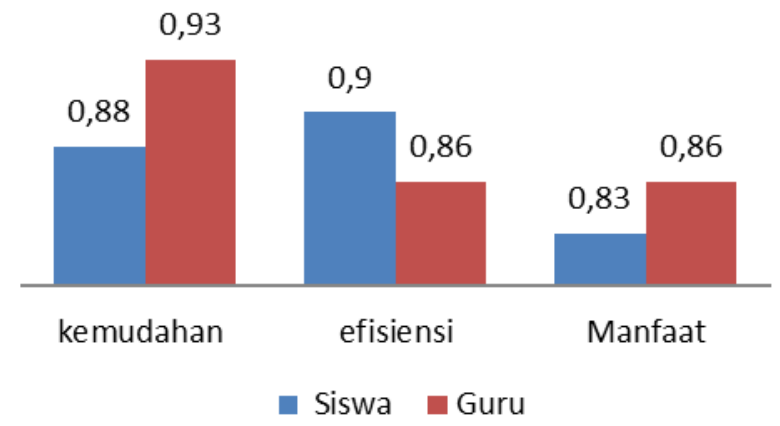

Gambar 4. Hasil Analisis Praktikalitas LKPD laju reaksi dari Respon Guru dan Siswa.

Berdasarkan grafik di atas diperoleh hasil analisis data penilaian praktikalitas LKPD laju reaksi berbasis inkuiri terstruktur oleh guru dan peserta didik masing-masing komponen yaitu: Komponen kemudahan penggunaan LKPD laju reaksi oleh guru kimia SMA diperoleh momen kappa sebesar 0,93 dengan kategori sangat tinggi dan untuk peserta didik diperoleh momen kappa 0,88 dengan kategori sangat tinggi. Hasil penilaian komponen efisiensi waktu oleh guru diperoleh momen kappa sebesar 0,86 dengan kategori sangat tinggi dan peserta didik diperoleh momen kappa sebesar 0,9 dengan kategori sangat tinggi. Selanjutnya untuk komponen manfaat LKPD oleh guru diperoleh momen kappa sebesar 0,86 dengan kategori sangat tinggi dan peserta didik diperoleh momen kappa sebesar 0,83 dengan kategori sangat tinggi.

\section{Simpulan}

Berdasarkan penelitian yang telah dilakukan, maka telah dihasilkan LKPD laju reaksi berbasis inkuiri terstruktur untuk kelas XI SMA dengan menggunakan model pengembangan 4-D. LKPD yang dihasilkan sudah diuji kevalidan dan kepraktisannya. Berdasarkan analisis data, diperoleh pada uji validitas nilai rata-rata moment kappa sebesar 0,87 dengan kategori kevalidan yang sangat tinggi dan pada uji praktikalitas diperoleh nilai rata-rata moment kappa pada guru dan siswa yaitu 0,88 dan 0,87 dengan kategori kepraktisan sangat tinggi. Berdasarkan hasil uji validitas dan praktikalitas dapat disimpulkan bahwa LKPD laju reaksi berbasis inkuiri terstruktur telah valid dan praktis.

\section{Referensi}

[1] Nazar, Muhammad, Sulastri, Sri Winarni, dan Rakhmi Fitriana. 2009. Identifikasi Miskonsepsi Siswa SMA Pada Konsep Faktor-faktor yang Mempengaruhi Laju Reaksi. Prodi Pendidikan Kimia Unsyiah Banda Aceh..

[2] Marthafera, Prisila, Husna Amalya Melati, dan Lukman Hadi. 2016. Deskripsi Pemahaman Konsep Siswa Pada Materi Laju Reaksi. Progaram Studi Pendidikan Kimia FKIP Untan Pontianak.

[3] Fahrucah, Eren dan Bambang, Sugiarto. 2012. Pengembangan Lembar Kerja Siswa pada Pembelajaran Kimia SMA Kelas XI Pokok Bahasan Faktor-faktor yang Mempengaruhi Laju Reaksi Melalui Pendekatan Scaffolding. Unesa Journal of Chemical Education, 1 (1): 93.

[4] Trianto. 2009. Mendesain Model Pembelajaran Inovatif-Progresif: Konsep. Landasan dan Implementasinya pada Kurikulum Tingkat Satuan Pendidikan (KTSP). Jakarta: Kencana 
Prenda Media Group.

[5] Kementerian Pendidikan Nasional. 2010. Juknis Pengembangan Bahan Ajar SMA. Jakarta. Direktorat Pembinaan SMA.

[6] Hosnan, Muhammad. 2014. Pendekatan Saintifik dan Kontekstual dalam Pembelajaran Abad 21. Bogor. Ghalia Indonesia.

[7] Banchi H., \& Bell R. (2008). "The Many Levels of Inquiry”. Science and Children. 46(2), 26-29.

[8] Zion,Michal dan Ruthy Mendelovici.2012. Moving from Structured to Open Inquiry:Challenges and Limits. Science Education Internasional. Vol.23.No.4.Hlm.383-399.

[9] Maryati, Anita Mariana. 2015. "Lembar Kerja (LKS) Eksperimen dan Non- Eksperimen Berbasis Inkuiri Terstruktur yang dikembangkan pada Subpokok Materi Pergeseran Kesetimbangan Kimia”. Prosiding Simposium Inovasi dan Pembelajaran Sains 2015.

[10] Omrod, J. 2014. Psikologi Pendidikan Edisi ke-Enam. Jakarta: Erlangga.

[11] Sugiyono. 2012. Metode Penelitian Pendidikan. Bandung: Alfabeta.

[12] Rochmad. 2012. Model Pengembangan Perangkat Pembelajaran Matematika, Desain-Model Pengembangan. Jurnal Pendidikan Matematika Hal 14, Vol 3 No 1.

[13] Suryosubroto, B. 1993. Sistem pembelajaran dengan modul. Yogyakarta: bina aksara. 